\title{
Food habits in Britain
}

By D. H. Buss, Nutrition Section, Ministry of Agriculture, Fisheries and Food, London $S W_{I}$

It is probably true to say that, within months of birth, everyone in the world will have his own personal food preferences. These will be based on foods which have been made familiar to him either because they grow where he lives or because they can be transported there at reasonable cost, but his ultimate choice will be based on many additional personal and cultural factors. Among these are the foods which his parents prefer, any allergies or other health considerations perhaps including nutrition, and a vast number of social expectations, traditions and taboos.

Comparatively few people, however, can afford to indulge their tastes, and we find, for example, countries in Asia where rice consumption averages roo- $15^{\circ}$ $\mathrm{kg} /$ person per year (FAO, I97I), sufficient to provide more than $90 \%$ of the energy in the diets of most people. In Europe, there is now more scope for individual preferences to be expressed, but it is still possible to discern major national differences in dietary habits. The cuisine in each region was developed many centuries ago from local foods, such as olive (Oleo europa) oil and wine in Mediterranean countries, milk and meat in the grassier regions of the north, and fish in countries with extensive coastlines. Wheat, the basic cereal of European diets, can be supplemented by rice in Spain and Portugal, but is often displaced by oats and rye in Scotland and Scandinavia where the growing season is short. As trade developed, exotic foods were introduced and became comparatively important in Britain with her access to the resources of her Empire. Some foods, notably the potato, were successfully naturalized (and would have provided ascorbic acid which was otherwise likely to be in short supply in a diet consisting largely of bread, meat and ale), but others remained expensive luxuries especially out of season until the development in the last century of steamships and railways for fast transportation and canning and mechanical refrigeration for food preservation.

Table I shows, for very broad groups of foods, how the total supplies in the United Kingdom compare with those in three of our Common Market partners in the most recent year for which this is possible (Ministry of Agriculture, Fisheries and Food, 1976). Although the energy value is close to $13.5 \mathrm{MJ}$ (3200 kcal)/person per $d$ for almost every country in Europe, the relative contributions of different foods show considerable variations even at this level. Thus, the United Kingdom (with Eire) continues to drink more than twice as much whole liquid milk as elsewhere, and lamb continues to be an important meat. In contrast, cheese and wine are comparatively unimportant and the amounts of fruit and vegetables other 
than potatoes recorded for the United Kingdom remain among the lowest in Europe.

Table I. Supplies of major foodstuffs in selected European Economic Community countries, $1974^{-5}$ ( $\mathrm{kg} /$ person per year)

$\begin{array}{lrcrr} & \begin{array}{c}\text { United } \\ \text { Kingdom }\end{array} & \text { France } & \begin{array}{c}\text { West } \\ \text { Germany }\end{array} & \text { Italy } \\ \text { Milk, liquid } & 145 & 65 & 59 & 56 \\ \text { Cheese } & 6 & 15 & 10 & 11 \\ \text { Meat } & 74 & 97 & 89 & 65 \\ \quad \text { Beef and veal } & 24 & 30 & 23 & 25 \\ \text { Mutton and lamb } & 8 & 3 & <1 & 1 \\ \text { Pig meat } & 26 & 33 & 50 & 17 \\ \text { Poultry } & 12 & 14 & 9 & 15 \\ \text { Potatoes } & 99 & 95 & 92 & 37 \\ \text { Other vegetables } & 75 & 115 & 70 & 153 \\ \text { Fruit } & 48 & 79 & 116 & 108 \\ \text { Sugar, refined } & 46 & 38 & 36 & 29 \\ \text { Visible fats } & 22 & 24 & 25 & 23 \\ \text { Wheat } & 64 & 70 & 47 & 129 \\ \text { Wine (1) } & 6 & 103 & 23 & 103 \\ \text { Beer (1) } \dagger & 114 & 46 & 147 & 16\end{array}$

-From Ministry of Agriculture, Fisheries and Food (1976).

†From Organisation for Economic Co-operation and Development (1975).

National food habits are, however, better expressed at the table, for it is the ways in which the raw foods are prepared and combined that give each country or region its characteristic cuisine. Thus, in Italy the wheat is largely made into a rich variety of pastas but in France and the United Kingdom it is baked into different breads and eaten with cheese or jam. Cakes and biscuits are also important in the United Kingdom. There are national preferences, too, among the individual vegetables and fruit, but it is perhaps in the meat dishes that differences are most clearly seen, and the roast beef of England, sausages of Germany and meat-based sauces of Italy are now woven into folklore.

Examples of the differences between Britain and the Continent can be extended to every meal of the day and to almost any food, and confirm that there are indeed 'British food habits'. But there remain distinct differences in habits within Britain, and it is with these that this paper will be concerned. These differences can be seen between men and women (Bender, 1976), between adults and children especially in relation to the number of children in the family (Ministry of Agriculture, Fisheries and Food, 1978) and as a result of different economic and social factors (McKenzie, 1976). But in this paper some regional differences in food habits will be discussed. These differences occur in meal pattern, as with the greater emphasis on breakfast (especially a cooked breakfast) in Scotland; they also occur in the type of catering establishment frequented and the foods chosen therein; but most of all they occur in the foods bought for use in the home and the dishes into which these are made. 
Knowledge of individual food habits is open to all of us and especially to those whose job it is to prepare food, but a major contributor to the quantification of regional food habits over the past 35 years has been the National Food Survey (NFS) (Ministry of Agriculture, Fisheries and Food, 1977). This is a continuous enquiry into the food obtained for use within homes throughout Great Britain (unlike records of the total food supplies, Northern Ireland is not included within the NFS). About 7500 housewives participate each year, and each records in a special log-book the description, quantity and cost of all foods she obtains during I week, as well as descriptions of each meal and details of each person present. The results, including a nutritional interpretation, are presented each year for households with different incomes and of different family composition as well as in different regions.

First, however, the broad stability of the British dietary pattern as a whole is worthy of demonstration. Table 2 confirms that the British household diet continues to be based largely on bread and other cereal products, milk and other dairy products, meat, and a variety of fruit and vegetables. Fats and sugar are also important, although the consumption of sugar (and potatoes) has recently declined as has bread and fish consumption over a longer period. In contrast, consumption of cheese and vegetables other than potatoes has risen. But the amounts of milk, eggs, meat, visible fats, and fruit and vegetables as a whole have remained remarkably stable despite record rates of inflation, our entry into the European Economic Community, and particularly the catastrophic weather conditions in many food-producing areas in the 1970's.

Table 2. Quantities (oz/person per week) of major foods used in the home in Great Britain*

$\begin{array}{lrrr}\text { Period of survey ... } & 1955 & 1965 & 1975 \\ \text { Milk, liquid (pints) } & 4.8 & 4.9 & 4.8 \\ \text { Cheese } & 2.8 & 3.2 & 3.8 \\ \text { Eggs (no.) } & 4.2 & 4.8 & 4.1 \\ \text { Meat and meat products } & 34.4 & 37.6 & 37 \cdot 1 \\ \text { Fish } & 6.0 & 5.8 & 4.5 \\ \text { Fats, visible } & 11.9 & 11.9 & 11 \cdot 1 \\ \text { Sugar } & 17.6 & 17.6 & 11 \cdot 3 \\ \text { Potatoes } & 59.9 & 53.2 & 43.9 \\ \text { Other vegetables } & 31.9 & 34.8 & 40.1 \\ \text { Fruit } & 27.1 & 30.1 & 31.8 \\ \text { Bread } & 55.1 & 40.6 & 33.7 \\ \text { Other cereal products } & 24.9 & 25.7 & 23.5\end{array}$

-From Ministry of Agriculture, Fisheries and Food (1957, 1967, 1977).

Regional differences in food purchases have also remained remarkably steady since the demise of food rationing allowed them to re-emerge from the enforced uniformity of the 1940's (Table 3). The foods (and the regions) selected for this 
table are those where differences are among the greatest, for the consumption of most staples such as liquid milk, eggs, potatoes and even meat as a whole rarely diverges by more than $5 \%$ from the national average.

Table 3. Selected regional differences in household food consumption (\% deviations from the national average) in Great Britain*

\begin{tabular}{lcccccc} 
Region... & \multicolumn{2}{c}{ London } & \multicolumn{2}{c}{ Wcotland } & Wales \\
\cline { 2 - 6 } Period of survey & $1956-60$ & $1970-5$ & $\overbrace{1956-60}$ & $1970-5$ & $\overbrace{1956-60}$ & $1970-5$ \\
Beef and veal & +1 & +9 & +24 & +28 & -14 & -4 \\
Mutton and lamb & +38 & +47 & -61 & -56 & +13 & +8 \\
Pork & +15 & +25 & -72 & -57 & +12 & +6 \\
Poultry & +49 & +30 & -33 & -31 & +10 & +6 \\
Butter & +2 & +7 & -10 & -12 & +58 & +31 \\
Margarine & -20 & -33 & +4 & +9 & -24 & -20 \\
Fresh green vegetables & +28 & +19 & -61 & -54 & +5 & +6 \\
Fresh fruit & +30 & +30 & -21 & -19 & +2 & -3 \\
Coffee & +21 & +11 & -54 & -29 & -51 & -27 \\
Tea & +2 & +1 & -12 & -10 & +1 & +5
\end{tabular}

-From Ministry of Agriculture, Fisheries and Food (1967, 1977).

Londoners, however, do buy substantially more meat than average, especially lamb, pork and poultry, and also more fresh green vegetables and fruit. The Scots reverse this pattern, and depend more on beef, meat products and starchy foods, while a continuing characteristic of the Welsh is a marked preference for salty butter over margarine. There are also much greater regional preferences for coffee than for tea, although, as with other extremes in food habits, there is evidence for a regression towards the mean as people migrate between regions and as advertising and other pressures become more uniform. Yet regional differences in the nutritional value of the diet are very small: the greatest departures are for ascorbic acid in London and Scotland, and these are only $15 \%$ from the national average. Whether the greater regional pride which is now developing will show itself in a renewal of dietary differences, or whether the present preferences of Londoners will be pursued elsewhere as in the past, remains for the future to tell.

The detailed NFS records of food purchases do, however, conceal some other differences. For example, information from the Meat and Livestock Commission (1975) shows that beef slaughtered in Scotland contains more fat than elsewhere in Britain (Table 4); but whether the beef eaten in Scotland can be identified with this, or whether much of the meat fat everywhere is discarded before consumption, are other questions.

Other regional differences are seen from the rich variety of traditional meat products still finding favour in the Midlands, North (west) of England and Scotland. These include meat pies, sausages, and such delicacies as faggots, tripe, black pudding and haggis. Cornish pasties are also still popular in their place of origin, but London is exceptional in its interest in foreign meat dishes such as lasagna and boeuf stroganoff. Such preferences are, of course, widely followed 
Table 4. Relative amounts (\%) of beef carcases falling within specified fat classes in selected regions of Great Britain, 1973-4"

Fat class...

Subcutaneous fat in carcase $(\mathrm{g} / \mathrm{kg}) \ldots$

South-east England

Yorkshire and Lancashire

South Scotland

North Scotland

$\begin{array}{ccccc}\text { I } & 2 & 3 & 4 & 5 \\ <45 & 45-74 & 75-104 & 105-134 & \geqslant 135 \\ 2 & 29 & 62 & 7 & <1 \\ 4 & 54 & 37 & 4 & <1 \\ 1 & 19 & 54 & 24 & 3 \\ <1 & 9 & 48 & 35 & 7\end{array}$

-Adapted from Meat and Livestock Commission (1975).

through in commercial catering, schools, hospitals and industrial canteens (Hughes, 1976, 1977).

There are also strong regional preferences in vegetables, not only for fresh green and exotic vegetables in the south of England and root vegetables in the north of England but also within a single type of vegetable as shown in Fig. I. Although total purchases of peas (Pisum sativum) are similar in London and the north of England at approximately $5 \mathrm{oz} /$ person per week, those in the north of England are almost entirely 'processed' peas (i.e. canned dried peas) while in London frozen peas are relatively important and those canned peas which are eaten are 'garden' peas (i.e. canned fresh peas). And 'mushy' peas are popular too in the Midlands and North-west of England.

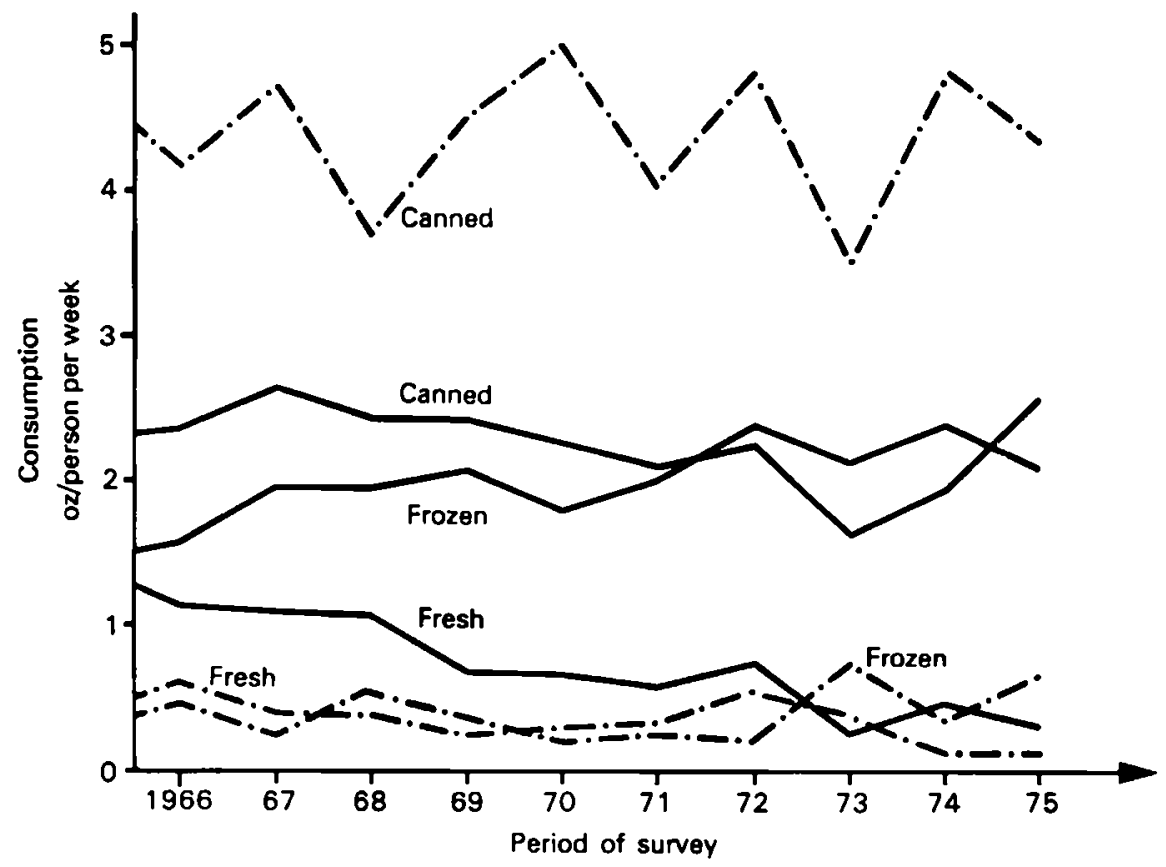

Fig. I. Household purchases of peas (Pisum satioum) in London (-) and the north of England $(-\cdot-\cdot)$. 
Another factor which is not apparent from published NFS records is the increasing diversification within some of the composite items. Thus not only have purchases of frozen 'other vegetables' increased everywhere alongside those of frozen peas, beans and chips, but they now include more corn-on-the-cob (Zea mays) courgettes (Cucurbita maxima) and other exotic items.

The dishes which are made from these food purchases also vary in the different regions of Britain. These are not covered in the NFS, but Hughes $(1976,1977)$ has recently completed a major survey of regional food preferences which includes an account of meal patterns in different parts of the catering sector. Among her conclusions are the preferences for 'filling' foods in the cooler north of Britain: in Scotland, for example, main meals often start with thick soups, and potato dishes are popular as are 'made-up' meat dishes with minced beef (but not pork). In the north of England, too, bakery goods and heavy desserts such as steamed and baked puddings with generous portions of custard are widely eaten. Hughes (1976, 1977) found that chips are popular everywhere, but fried fish are especially popular in Yorkshire and Humberside. There are also distinct regional differences in the type of fish eaten. Among the dishes found to be most popular in the south-east of England were salads, foods with 'foreign-sounding' names, and lighter desserts including fresh fruit. Most of these preferences were reported for all forms of catering institution, and appear to be of long standing.

No account of British food habits should omit the contribution made by immigrants to our diet. Although foreign travel has widened the tastes of some of us, the substantial number of immigrants we have received in the past two decades has done far more. Some of these people settled in communities of their own, and the local shops soon adapted to the new demands so that West Indian foods were brought to Brixton, Indian ones to Southall and the Midlands and Greek to Camden. But some cultures have made a far greater impact on the diet of the nation as a whole: Chinese food was almost unknown in Britain until the 1950's, yet almost every community now has its 'Chinese take-away' to rival the 'fish-andchip' shop, and nearly everyone has eaten curry, hamburgers and fried chicken. Indeed, sales from foreign restaurants are estimated to have reached $f_{0} 160000000$ and from oriental and other 'take-away' shops (excluding 'fish-and-chip' shops) a further $\oint_{0} 90000000$ out of total expenditure of $\ell_{1} 200000000 /$ year on food in catering establishments (Hales, 1977).

In conclusion, it should be remembered that our food habits and preferences have developed over centuries. They were originally imposed by climatic and financial limitations but, even after these receded, there were and still are strong regional preferences passed on from parent to child. Both the age at which these develop and the potential for change are nicely illustrated by a recent study of primary school children from a poor area of Sheffield and an affluent area of Hampshire: those in Sheffield were found to prefer chips, baked beans, sausages, fish fingers and many processed foods with synthetic flavours, while in Hampshire pizzas, curries, salads and oriental foods were among the most popular (Thomas \& Osner, 1976). 


\section{REFERENCES}

Bender, A. E. (1976). Proc. Nutr. Soc. 35, $18 \mathrm{r}$.

FAO (1971). Food Balance Sheets 1964-66. Rome: FAO.

Hales, A. (1977). Brevers' Guardian 106, 17.

Hughes, M. L. (1976). Regional food preferences. PhD Thesis, University of Surrey, Guildford.

Hughes, M. L. (1977). Hotel Catering and Institutional Management Association Review 2,78 .

Mckenzie, J. (1976). In People and Food Tomorrow, [D. Hollingsworth and E. Morse, editors]. London: Applied Science.

Meat and Livestock Commission (1975). Progress on Beef Carcase Classification (Technical Bulletin no. 22). Milton Keynes: Meat and Livestock Commission.

Ministry of Agriculture, Fisheries and Food (1957). Domestic Food Consumption and Expenditure: 1955. London: HM Stationery Office.

Ministry of Agriculture, Fisheries and Food (1967). Household Food Consumption and Expenditure: 1965. London: HM Stationery Office.

Ministry of Agriculture, Fisheries and Food (1976). E.E.C. Agricultural and Food Statistics 1972-75. London: Ministry of Agriculture, Fisheries and Food.

Ministry of Agriculture, Fisheries and Food (1977). Household Food Consumption and Expenditure: 1975. London: HM Stationery Office. (In the Press).

Organisation for Economic Co-operation and Development (1975). Food Consumption Statistics 1955-73. Paris: Organisation for Economic Co-operation and Development.

Thomas, S. \& Osner, R. C. (1976). Proc. Nutr. Soc. 35, 36A. 